\title{
UKRAINIAN GREEK CATHOLIC CHURCH'S STANCE VIS-À-VIS TERRORIST ACTIVITIES OF UKRAINIAN NATIONALISTS IN THE EARLY 1930S
}

\author{
Mieczysław Ryba \\ The John Paul II Catholic University of Lublin \\ Department of the Spanish World, Politics and International Relations \\ Katolicki Uniwersytet Lubelski Jana Pawła II \\ Katedra Świata Hiszpańskiego, Polityki i Relacji Międzynarodowych \\ e-mail: lipin@kul.lublin.pl
}

\begin{abstract}
The article discusses the reaction of the Greek Catholic Church to terrorist attacks in the Polish lands by Ukrainian nationalists in the 1930s. Greek Catholic bishops (Andrei Sheptytsky, Josaphat Kotsylovsky, Hryhoryi Khomyshyn) supported the creation of the Ukrainian state in 1918. After the defeat of Ukrainians in the war with Poland in 1919, the nationalist movement was born in the Eastern Lesser Poland. The movement departed significantly in its ideology from the Christian values. The peak of the nationalism was the turn of the 1920s and the 1930s. On the one hand, there was a surge in terrorist attacks by the Ukrainian Military Organization and the Organization of Ukrainian Nationalists. On the other hand, the chauvinist ideology of Dmytro Dontsov was becoming increasingly influential. All this led to unrest among Ukrainian bishops. The attacks were severely criticized by Bishop Hryhoryi Khomyshyn, who condemned the pagan nationalism in all of its forms. The reaction of Metropolitan Andrei Sheptytsky was more toned down, which sparked tensions between the two clergymen.
\end{abstract}

Keywords: Ukrainian nationalism, Andrei Sheptytsky, Hryhoryi Khomyshyn

Terrorist attacks perpetrated by the Ukrainian nationalists date back to the preWorld War I period. A prime example of this type of activity was the assassination of the governor-general of Galicia (Halychyna), Andrzej Kazimierz Potocki in 1912 (he was murdered by an Ukrainian college student, Myroslav Sichynsky) ${ }^{1}$. Terrorist activities intensified particularly in the interwar period, especially after Ukrainians lost their war with Poland in 1919. One of the most widely reported attacks was an

1 C. Partacz, Od Badeniego do Potockiego. Stosunki polsko-ukraińskie w Galicji w latach 1888-1908 ['From Badeni to Potocki. Polish-Ukrainian relations in Galicia in the period of 1888-1908'], Torun 1996, p. $227 \mathrm{f}$. 
attempt to assassinate Marshall Józef Piłsudski, undertaken by the activists of the Ukrainian Military Organization (Ukrayins'ka Viys'kova Orhanizatsiya, UVO). The incident took place on September 25th, 19212.

The UVO carried out attacks not only on Poles but also on Ukrainians, whenever the latter advocated some sort of political cooperation with Polish authorities. Such was the case of Sydir Tverdokhlib, a renowned professor, outstanding linguist, and an active Ukrainian patriot, murdered on October 15th, 1922. Despite his excellent merits acquired in the field of Ukrainian cultural life the decision to kill him was made due to his critical position towards murderous activities of Ukrainian nationalists ${ }^{3}$.

Shortly afterwards the UVO launched a large-scale terrorist action in Eastern Lesser Poland region ${ }^{4}$. Such overwhelming wave of acts of terrorism might have been aimed at instigating an anti-Polish uprising in this area. However, international recognition of the Polish eastern border in 1923, together with the effective action taken by Polish police and military, put an end to this terror spree 5 .

A second series of terrorist attacks in Eastern Lesser Poland was organized by the UVO and the Organization of Ukrainian Nationalists (Orhanizatsiya Ukrayins 'kykh Natsionalistiv, OUN $)^{6}$ from July to November 1930. In a similar manner to the events of early 1920s, the action was aimed against both local Polish population and their peaceful Ukrainian neighbors. Historians report several hundred acts of arson, disrupted telegraph lines, and damaged railway tracks, accompanied by killings. In an interview published by the London-based "The Times", the leaders of Ukrainian nationalists declared that year that they did not want peace with Poland and would reject any offer coming from that direction ${ }^{7}$. Such terror tactics of the OUN was aimed at provoking a retaliatory action of Polish authorities and thus

2 L. KulińsKa, Działalność terrorystyczna i sabotażowa nacjonalistycznych organizacji ukraińskich $w$ Polsce $w$ latach 1922-1939 ['Terrorism and sabotage of Ukrainian nationalist organizations in Poland in the period of 1922-1939'], Kraków 2009, p. 179f.

3 Ibidem, p. 181.

4 Ibidem, p. 144-184.

5 Ibidem, p. 184. Cf. L. KulińsKa, Terroryzm w II RP-Ukraińska Wojskowa Organizacja i Organizacja Ukraińskich Nacjonalistów ['Terrorism in the 2nd Polish Republic. The Ukrainian Military Organization and the Organization of Ukrainian Nationalists'], "Bezpieczeństwo. Teoria i praktyka" ['Security. Theory and Practice'], 2(2016), p. 89-100.

6 R. Wysocki, Organizacja Ukraińskich Nacjonalistów w Polsce w latach 1929-1939 ['Organization of Ukrainian Nationalists in Poland in 1929-1939'], Lublin 2003, p. 45; Archiwum Akt Nowych ['The Central Archives of Modern Records, Warsaw, Poland'], Ministerstwo Spraw Zagranicznych: 1918-1939 ['Ministry of Foreign Affairs Fond: 1918-1939'], Notatka informacyjna o wypadkach w Małopolsce Wschodniej ['A report on the incidents in Eastern Lesser Poland'], file No. 2253, p. 98f.

7 W. PobóG-Malinowski, Najnowsza historia polityczna Polski. 1864-1945 ['The latest political history of Poland. 1864-1945'], vol. 2, part 1, London 1956, p. $535 f$. 
keeping tensions high in the region. In fact, in the last weeks of 1930 Józef Piłsudski issued orders for the Polish Army to launch a pacification operation across Eastern Lesser Poland.

Such state of affairs was met with responses coming from Greek Catholic bishops who declared themselves Ukrainian ever since the independent Polish Republic was back to life. They were fully aware of the fact that the ideology proclaimed by Dmytro Dontsov (with his extremely important book: Nationalism) was the most influential factor of radicalization within Ukrainian society ${ }^{8}$. Fanatic nationalism was particularly strongly criticized by the milieu gathered around the Greek Catholic bishop of Stanisławów (today: Ivano-Fankivsk), Hryhoriy Khomyshyn. The newspaper "Nova zorya" ('The New Star') was one of the most prominent press titles connected with the Bishop. One opinion piece in "Nova zorya" observed that the reverence shown by Ukrainian nationalists to Dontsov's Nationalism was comparable only to how fundamental for the communists was Karl Marx's Capital ${ }^{9}$. The newspaper traced the roots of nationalism back to the French Revolution and the 19th-century philosophical idealism, quite in line with the reasoning of European and Polish conservatives of the day. Another opinion declared the late 19th-century German nationalism to be an exceptionally dangerous one. It was also stated that the only acceptable form of nationalism would have been the one referring to Christianity as its basic idea ${ }^{10}$.

In another article, "Nova zorya" compared Ukrainian nationalism to socialism and communism, which were all based on materialism. Idolatrous deification of the nation was deemed exceptionally horrifying ${ }^{11}$. According to the newspaper, it was impossible to develop human culture without religion understood as a foundation of human life. Instrumental approach to religious matters was in Catholic Church strictly forbidden. No group of people linked with Catholicism, it was stated, could therefore support enemies of religion. And both socialism and materialistic nationalism were judged in the newspaper as belonging to one and the same category: enemies of religion ${ }^{12}$.

The milieu gathered around Bishop Khomyshyn on the one hand condemned Ukrainian nationalism, and on the other hand opposed the pacifying operation inflicted upon Lesser Poland villages and townships after the second wave of UVO

\footnotetext{
8 W. Poliszczun, Doktryna Dmytro Doncowa. Tekst. Analiza ['The doctrine of Dmytro Dontsov. The text and analysis'], Toronto 2006, p. 310; T. STRYJEK, Ukraińska idea narodowa okresu międzywojennego ['Ukrainian national concept in the interwar period'], Torun 2013, p. 138-140.

9 В. Миропільский [=V. MүropILSKIY], Націоналізм, “Нова зоря”, 5.01.1930, р. 3.

${ }^{10}$ Ibidem, p. $3 \mathrm{f}$.

${ }^{11}$ Найвисша иуінність. Про матеріялізм, начіоналізм і релігію, “Нова зоря”, 14.09.1930, p. 2.

${ }^{12}$ Ibidem.
} 
attacks (1930). The opinion was that applying collective responsibility would be completely ineffective. Against the wishes of Polish authorities these actions obviously gave rise to resentment among Ukrainian population, and indeed strengthened the influence of OUN, or, alternatively, of the Bolsheviks ${ }^{13}$. A deeper cause of the Polish-Ukrainian conflict was pointed out: the lack of safeguarding the rights of Ukrainians as a nation ${ }^{14}$.

The radicalization of moods among Ukrainian population in Eastern Lesser Poland was a worrying sign for other Greek Catholic bishops as well. They were: Metropolitan Andrei Sheptytsky and Bishop Josaphat Kotsylovsky. For this reason they co-authored and issued a pastoral letter calling for a positive effort to ameliorate the life of the nation in close connection with the Church and Christian faith. Tackling the problem of terrorist attacks of 1930 they spoke against underground activities, speaking also against anarchy and Bolshevism as threats to the nation ${ }^{15}$.

However, another pastoral letter reverberated much stronger. It was Pastoral letter on the political situation of the Ukrainian nation in the Polish State, by Bishop Khomyshyn ${ }^{16}$. This letter was widely discussed in both Polish and Ukrainian circles, and became the object of attacks by chauvinistic groups ${ }^{17}$. Bishop Khomyshyn condemned Ukrainian nationalism but did spare neither Ukrainians nor Poles in his criticism. In general, the Bishop indicated how this intense conflict between two nations could be ended. But this was not to the liking of Ukrainian nationalists, and their press insulted him in return ${ }^{18}$. In an interview granted to "Gazeta Poranna" ("Morning Paper") with regard to his pastoral letter, the Bishop talked about the need for reaching a Polish-Ukrainian agreement in the entire Eastern Galicia. As he pointed out, the degree of tension and hatred was extremely high.

13 “Помиляються польське громадянство й урядові чинники, коли думають, що такими 'реванжами’ і ‘нацифікаціями’ осягнуть бажану ними ціль: втихомирити українське населення нашого краю та прив'язати його до себе і до держави. Такою політикою вони тільки роздратують українське населення до краю та заженуть молодші й живіші його елементи як раз до УВО або до большовиків. А ся перспектива зовсім не усміхається величезній більшости українського громадянства в Польщі”. Слово до польського громадянства. Про саботажі, реванжі і пацифікацію. На чий млин вода?, “Нова зоря”, 2.10.1930, p. 2.

${ }^{14}$ Що діється в нашім краю, "Нова зоря”, 2.10.1930, р. 1.

${ }^{15}$ Пастирський лист сімох гр.-кат. Владик, 13 жовтня 1930, “Нова зоря”, 26.10.1930, p. 1.

${ }^{16}$ Г. Хомишин [=Н. КномүSнуN], Пастирський лист про політичне положення украӥнського народу в польській державі, Дано в Станиславові 23 лютого 1931 в перший день Великого Посту, "Нова зоря”, 22.03.1931, р. 5-9.

${ }^{17}$ Вражіння з Пастирського Листа, “Нова зоря”, 26.03.1931, p. 1.

${ }^{18}$ G. Chomyszyn [=H. Khomyshyn], Problem ukrainski. Odbitka artykułów z XXIX i XXX (marzeckwiecień-maj 1933) tomu miesięcznika „Nasza Przyszłość. Wolna Trybuna Myśli Zachowawczej” ['The Ukrainian problem. Articles collected from vols. 29 and 30 (for March, April, and May of 1933) of the monthly "Our Future. A Free Tribune of Conservative Thought"'], Warszawa 1933, p. $25 \mathrm{f}$. 
Khomyshyn proposed creating platforms for Polish-Ukrainian political, economic, and cultural cooperation. "Nova zorya" echoed this by stressing that such work of reconciliation could only be done by serious and experienced people ${ }^{19}$.

On August 29th, 1931, in Truskavets, Ukrainian nationalists murdered Tadeusz Hołówko, a well-known adherent of Piłsudski. Hołówko was likely the most outspoken supporter of the so-called Promethean idea, i.e. that of the emancipation and full, equal rights for all nationalities living within Polish borders which, for example, entailed the postulate of territorial autonomy of Eastern Lesser Poland ${ }^{20}$. In reaction, Metropolitan Sheptytsky wrote a pastoral letter entitled $A$ word to Ukrainian youth but from the memoirs of Bishop Khomyshyn we know that this was done under strong pressure coming from Stanisławów ${ }^{21}$. Sheptytsky's letter to Ukrainian youth was somewhat soft in its character. At least such was the way in which it was perceived by Khomyshyn who, in his memoirs, openly suggested that in this regard the Metropolitan Archbishop of Lviv committed the sin of omission ${ }^{22}$. Khomyshyn, on the other hand, reacted in a very strong way. The authors in "Nova zorya" were profoundly shaken by the murder of Hołówko. Terror tactics of the OUN was condemned in the newspaper in no uncertain terms ${ }^{23}$. Furthermore, the intentions of the terrorists were diagnosed very accurately. These attacks, it was stated, were aimed at provoking Polish authorities to retaliatory actions which, in turn, would further radicalize Ukrainian population, leading up to a national insurgency. The proof that such a perverted policy was being implemented was that Hołówko sought an agreement between Poles and Ukrainians with great dedication, and was murdered

${ }^{19}$ Розмова з Їх Екси. Преосв. Г. Хомишином, “Нова зоря”, 29.03.1931, p. 2f.

${ }^{20}$ Śp. Tadeusz Hołówko wobec problemów narodowościowych ['The late Tadeusz Hołówko’s position on the problems of nationality'], "Sprawy Narodowościowe" ['Nationality Issues'], 4/5(1931), p. 381-384. Cf. T. Hoєówкo, Kwestia narodowościowa w Polsce ['The question of nationality in Poland'], Warszawa 1922, p. 6-29.

${ }^{21}$ E. Prus, Patriarcha galicyjski. Rzecz o arcybiskupie Andrzeju Szeptyckim, metropolicie grekokatolickim (1865-1944) ['Galician patriarch. The story of the Greek Catholic archbishop Metropolitan Andrei Sheptytsky (1865-1944)'], Wrocław 1999, p. 137.

${ }^{22}$ Memoirs recently published as G. Chomyszyn [=H. Khomyshyn], Dwa królestwa ['Two kingdoms'], ed. I. Pełechatyj, W. Osadczy, Kraków 2017. On page 88, we read: “The Metropolitan neglected all this, and for this reason, instead of a sober and reasonable policy acts of terror entered the stage, perpetrated by underground militias, drafting our youth, organized by various self-styled 'chiefs'. The Metropolitan not only did not fulfill that duty but took a passive stance towards terrorists, or maybe rather supported them in an indirect manner, either way expressing his approval with his silence. On the occasion of death or execution of one of such providnyks [leaders] [...] memorial service is held in St. George's Cathedral. When two young boys, Bilas and Danylyshyn, who murdered Hołówko, a brave and important Pole, in Truskavets, were sentenced to death by hanging, in the hour of their execution St. George's bells were tolling".

${ }^{23}$ Террор, “Нова зоря”, 3.09.1931, р. 1. 
nonetheless. "Nova zorya" emphasized that terror and insurrectionary methods did not constitute effective measures to reach Ukrainian independence at all. Actions of Bohdan Khmelnytsky were regarded as a historical example of this. "Nova zorya" completely rejected terrorist methods of the OUN, calling upon them to come to their senses ${ }^{24}$.

In Ukrainian Catholic press, the murder of Hołówko was followed by a series of articles criticizing the OUN. On October 8th, the daily newspaper "Meta" ('The Aim'), associated with the Metropolitan Sheptytsky, described activities of the OUN in the following words:

Society, and youth in particular, must learn it perfectly well, that revolution cannot be made at all cost, for instance, with the help of students of secondary schools. Furthermore, the revolution requires not only people ready to sacrifice and take risks but most of all people of integrity. [...] Three factors are missing in the underground: political sense, moral foundation and an appropriate social class that would regard national revolution as a social issue.

In another issue of "Meta" the trial of the killers of Hołówko was analyzed, and firm conclusions were drawn: "The conjuncture established by the Sambor Trial opens up an opportunity to review our policies. Ukrainian conspiracy in its current form has been discredited from its foundations up to the very top. It no longer constitutes a factor that would be capable of self-renewal". And, from another part of the text: "Our Ukrainian, legally printed press, as well as our legally publishing authors is largely responsible for what has been developed in the underground. They were reluctant to discuss even those phenomena of which they knew how harmful they were" 25 .

"Nova zorya" expressed it in an even more straightforward manner. First of all, a slogan repeated among Ukrainian population: "All or Nothing", was criticized. Those responsible for pushing young boys into the depths of conspiracy were not only the Poles - it was stated - but also Ukrainian society itself. If not for this maximalist approach, relations with the Poles could be entirely different. Society was too forbearing towards the irresponsibility of its youth. "Nova zorya" also suggested that real responsibility for the crimes lied with those who manipulated the youngsters. Youth must be therefore freed from the clutches of provocateurs whose actions are detrimental to the Ukrainian cause ${ }^{26}$.

But even more fear and dread in Catholic circles was caused on June 15th, 1934, when the Minister of Interior, Bronisław Pieracki, was assassinated. This Polish

\footnotetext{
${ }^{24}$ Ibidem, p. $1 \mathrm{f}$.

${ }^{25}$ All quotes from Polish translations in: "Sprawy Narodowościowe", 5(1933), p. 557.

${ }^{26}$ Ibidem, p. 558.
} 
politician approached Ukrainians in a reconciliatory manner and was a supporter of the recognition of full rights of nationalities living within the borders of the Polish Republic. Targeting and murdering such a figure made no sense whatsoever from a moderate Ukrainian's point of view ${ }^{27}$.

However, the most painful blow to the ecclesiastic Ukrainian circles came on July 25th, 1934, with the murder of the headmaster of the Ukrainian secondary school in Lviv, Ivan Babiy. He was a close associate of Metropolitan Sheptytsky and a Ukrainian patriot who opposed the involvement of young people in terror attacks. The Metropolitan voiced his opinion on this homicide, and his press organ, "Meta", used strong words. On August 5th its pages contained the following:

\begin{abstract}
This tragic "for what?", all that guesswork regarding any reasonable political motive, presents itself as a foreboding question mark hanging over the recent political assassinations: Hołówko, Pieracki, Babyi. Perhaps those acts will never get any justification, even from among revolutionary reasons. This is why - in times when such an incredible experiment in political stupefying and physical destruction of Ukrainian nation unfolds before our very eyes - revolutionary acts like these cannot be described otherwise than as a push towards double political suicide. This description is further corroborated by the uproar in Polish chauvinistic circles after each murder, by current working climate in legal Ukrainian institutions, and by each and every act of limiting the field of their work. [...] Therefore even at this point it does not matter which group is responsible for the death of the late I[van] Babiy. What is important is that some sinister demon infused Ukrainian reality with the actual feasibility of political assassinations with no political sense at all: they are committed simply "off the wall". This cannot be called otherwise. Perplexities in the case of the late Mr. Hołówko, together with the Sambor Trial are fresh in our memory. Leaders of the OUN have not taken responsibility for this up till now. The same goes for the assassination of Minister Pieracki. Even the most far-fetched hypotheses cannot explain this - given that they will be based on a sane mind - in terms of reasons the Ukrainian underground might have had ${ }^{28}$.
\end{abstract}

The murder of Babiy was a genuine shock to the Ukrainian Greek Catholic circles. He was a well-known Ukrainian patriot, an associate of Metropolitan Sheptytsky, and an active member of Catholic Action. The article in "Meta" that discussed this homicide wrapped the subject-matter up as follows:

Let us hope that the death of HM Babiy will not only shake Ukrainian society to the core but also will sober it up in a decisive manner. Let us hope that it will be followed by a climate where such crimes will no longer be possible. And if they continue, they will be met with no answer whatsoever, as acts of sheer banditry ${ }^{29}$.

\footnotetext{
27 Quote from "Sprawy Narodowościowe", 2/3(1934), p. 146f.

${ }^{28}$ Quote from "Sprawy Narodowościowe", 4(1934), p. 433f.

${ }^{29}$ Ibidem.
} 
Metropolitan Sheptytsky wrote a special letter on this occasion, which was subsequently published by majority of Ukrainian press. Among other things, we find there this passage:

HM Babiy fell victim to Ukrainian terrorists. An overwhelming sense of dread gripped the entire nation. In a treacherous manner they killed an outstanding patriot, a distinguished citizen, an excellent educator, a well-known and highly regarded friend, caretaker, and benefactor of Ukrainian youth. They killed for no reason, perhaps only because they did not like educational policies of the deceased. It was an impediment to their criminal action of luring students at the secondary level into the underground work. If that is indeed the case, every distinguished and reasonable Ukrainian will be slain by assassins, as there is no reasonable Ukrainian who would not oppose such a criminal act. There are no educators, there are no teachers who would not admit that it is a serious crime against young people to lure them into this kind of work and introduce them to the underground. No father or mother would lead their young into the wilderness of crime. If you want to kill treacherously all those who oppose your work, you will have to kill all teachers and professors who work for Ukrainian youth, all fathers and mothers of Ukrainian children, all chairmen and headmasters of Ukrainian educational institutions, all politicians and social activists, but above all you will have to send assassins to remove the obstacles to your criminal and stupid work placed by the clergy, including bishops. For we have been telling it for many years, and we will never stop repeating, that a crime is always a crime, and one cannot serve the sacred cause with bloodied hands. We will never stop maintaining that whoever demoralizes youth is a criminal and an enemy of the nation ${ }^{30}$.

The Metropolitan also criticized leaders of the OUN who at the time lived abroad. Babiy, in turn, was praised in a highly exalted tone:

I call upon all colleagues and students of the late HM Babiy to give witness publicly to his virtues and merits. [...] Among many exceptional virtues of the deceased there was that rare one which he instilled into young people: courage. Knowing the danger, this officer of Ukrainian army performed a hard duty for our children, and did not leave his post, sacrificing his personal well-being and the welfare of his family ${ }^{31}$.

The press linked to the OUN declared their disbelief that Sheptytsky wrote this letter himself ${ }^{32}$. But several days later the Metropolitan issued another letter (published in "Lwowskie Diecezjalne Wiadomości" ("Lviv Diocesan Newsletter"). Its subject matter concerned the regulations regarding the use of religious services for political purposes. Ukrainian nationalists did just that very often. The Metropolitan clearly stated that using sacred things for purposes other than religious ones

\footnotetext{
${ }^{30}$ Ibidem, p. 435.

${ }^{31}$ Ibidem.

${ }^{32}$ Ibidem, p. 436f.
} 
"is a profanation, that is, a sacrilege forbidden in God's law". Sheptytsky took into account incidents of blackmailing his priests. For this reason, he wrote: "If during the service or directly afterwards some irresponsible individuals interfere with the order of service or sacred character of the location, e.g., through distribution of leaflets and singing lay songs, it is the duty of the priest who presides over the service to condemn such a conduct and discontinue the service, if possible" ${ }^{\prime 3}$. Both Sheptytsky's letters must have had a substantial impact on Ukrainian political milieus, because on August 23rd, 1934 "Meta" apparently tried to soothe the atmosphere in the article entitled Unnecessary sensations and damaging conjectures. Orders of the Metropolitan, it was said, were based on obvious premises and were not aimed against any particular political side ${ }^{34}$.

Bishop Khomyshyn, however, was still more explicit in his criticism of the nationalists and directly called things by their true name. He was scandalized by the fact that solemn memorial services were held in Greek Catholic churches for the souls of Vasily Bilas and Dmytro Danylyshyn, the executed murderers of Tadeusz Hołówko. And not the fact of prayer for the souls was scandalous but political manifestations that accompanied those prayers. Even his own cathedral in Stanisławów became the place of such an event, presided over by Redemptorist Fathers. In Bishop Khomyshyn's view this was just appalling ${ }^{35}$.

\section{CONCLUSION}

Radicalization of Ukrainian nationalist movement which took place at the turn of the 1920s and 1930s was met with a strong response of the Greek Catholic Church. Bishops of this Church, by principle, could not accept the ideology of Dmytro Dontsov and criminal activities of the UVO and the OUN. They banned nationalist political propaganda from their temples. It should be noted, however, that a much more firm position was adopted in this regard by Bishop Khomyshyn who, as early as 1920 s, condemned the forms in which Ukrainian nationalism manifested itself. Metropolitan Archbishop of Lviv, Andrei Sheptytsky, although he distanced himself from the actions of nationalists, took a significantly more moderate stance.

\footnotetext{
${ }^{33}$ Ibidem, p. 437.

34 "Мета", 23.08.1934; "Sprawy Narodowościowe", 4(1934), p. 438.

${ }^{35}$ G. Chomyszyn [=H. Khomyshyn], Dwa królestwa... ['Two kingdoms...'], p. $125 \mathrm{f}$.
} 


\section{BIBLIOGRAPHY}

\section{ARCHIVE MATERIALS}

Archiwum Akt Nowych ['The Central Archives of Modern Records, Warsaw, Poland'], Ministerstwo Spraw Zagranicznych: 1918-1939 ['Ministry of Foreign Affairs Fond: 1918-1939'], Notatka informacyjna o wypadkach w Małopolsce Wschodniej ['A report on the incidents in Eastern Lesser Poland'], file No. 2253.

\section{POLITICAL WRITINGS}

Сномyszyn G. [=Кномyshyn H.], Dwa królestwa ['Two kingdoms'], ed. I. Pełechatyj, W. Osadczy, Kraków 2017.

Сhomyszyn G. [=Khomyshyn H.], Problem ukrainski. Odbitka artykułów z XXIX i XXX (marzeckwiecień-maj 1933) tomu miesięcznika „Nasza Przyszłość. Wolna Trybuna Myśli Zachowawczej” ['The Ukrainian problem. Articles collected from vols. 29 and 30 (for March, April, and May of 1933) of the monthly "Our Future. A Free Tribune of Conservative Thought"'], Warszawa 1933.

НоєÓwко T., Kwestia narodowościowa w Polsce ['The question of nationality in Poland'], Warszawa 1922.

\section{PRESS}

“Мета", 1933-1934:

[As quoted in:] "Sprawy Narodowościowe" ['Nationality Issues'], 5(1933), 2/3(1934), 4(1934).

\section{“Нова зоря", 1930-1931:}

Вражіння з Пастирського Листа, “Нова зоря”, 26.03.1931.

Миропільский В. [=МүropilsкiY V.], Націоналізм, “Нова зоря”, 5.01.1930.

Найвисша цінність. Про матеріялізм, націоналізм і релігію, “Нова зоря”, 14.09.1930.

Про саботажі, реванжі і пацифікачію. На чий млин вода?, “Нова зоря”, 2.10.1930.

Розмова з Їх Екси. Преосв. Г. Хомишином, “Нова зоря”, 29.03.1931.

Террор, “Нова зоря”, 3.03.1931.

Хомишин Г. [=КномүSнYN Н.], Пастирський лист про політичне положення украӥнського народу в польській державі. Дано в Станиславові 23 лютого 1931 в периий день Великого Посту, “Нова зоря”, 22.03.1931.

Шептицький А., КоцилОвський Й. [=SHEPTYтSкy А., КотSYLOvSкy J.], Пастирський лист сімох гр.-кат. Владик, 13 жовтня 1930, “Нова зоря”, 26.10.1930.

Що діється в нашім краю, “Нова зоря”, 2.10.1930.

\section{"Sprawy Narodowościowe", 1931-1934:}

Śp. Tadeusz Holówko wobec problemów narodowościowych ['The late Tadeusz Hołówko’s position on the problems of nationality'], "Sprawy Narodowościowe", ['Nationality Issues'], 4/5(1931). 


\title{
LITERATURE
}

KuliŃSKa L., Działalność terrorystyczna i sabotażowa nacjonalistycznych organizacji ukraińskich $w$ Polsce w latach 1922-1939 ['Terrorism and sabotage of Ukrainian nationalist organizations in Poland in the period of 1922-1939'], Kraków 2009.

KulińsKa L., Terroryzm w II RP - Ukraińska Wojskowa Organizacja i Organizacja Ukraińskich Nacjonalistów ['Terrorism in the 2nd Polish Republic. The Ukrainian Military Organization and the Organization of Ukrainian Nationalists'], "Bezpieczeństwo. Teoria i praktyka” ['Security. Theory and Practice'], 2(2016).

Partacz C., Od Badeniego do Potockiego. Stosunki polsko-ukraińskie w Galicji w latach 1888-1908 ['From Badeni to Potocki. Polish-Ukrainian relations in Galicia in the period of 1888-1908'], Torun 1996.

PobóG-Malinowski W., Najnowsza historia polityczna Polski. 1864-1945 ['The latest political history of Poland. 1864-1945'], vol. 2, part 1, London 1956.

Poliszczuk W., Doktryna Dmytro Doncowa. Tekst. Analiza ['The doctrine of Dmytro Dontsov. The text and analysis'], Toronto 2006.

Prus E., Patriarcha galicyjski. Rzecz o arcybiskupie Andrzeju Szeptyckim, metropolicie grekokatolickim (1865-1944) ['Galician patriarch. The story of the Greek Catholic archbishop Metropolitan Andrei Sheptytsky (1865-1944)'], Wrocław 1999.

Stryjek T., Ukrainska idea narodowa okresu międzywojennego ['Ukrainian national concept in the interwar period'], Torun 2013.

Wysocki R., Organizacja Ukraińskich Nacjonalistów w Polsce w latach 1929-1939, Lublin 2003.

\section{STANOWISKO UKRAIŃSKIEGO KOŚCIOŁA GRECKOKATOLICKIEGO WOBEC DZIAŁAŃ TERRORYSTYCZNYCH UKRAIŃSKICH NACJONALISTÓW NA POCZĄTKU LAT TRZYDZIESTYCH XX WIEKU}

\begin{abstract}
Streszczenie. Artykuł dotyczy reakcji Kościoła greckokatolickiego na zamachy terrorystyczne organizowane na ziemiach polskich przez nacjonalistów ukraińskich w latach trzydziestych XX w. Biskupi greckokatoliccy (Andrzej Szeptycki, Jozafat Kocyłowski, Grzegorz Chomyszyn) poparli budowę państwa ukraińskiego w 1918 r. Po klęsce Ukraińców w wojnie z Polską w 1919 r. rozwinął się w Małopolsce Wschodniej ruch nacjonalistyczny, znacząco odbiegający w swych podstawach ideowych od zasad chrześcijańskich. Szczególne wzmożenie owego nacjonalizmu nastąpiło na przełomie lat dwudziestych i trzydziestych XX w. Z jednej strony nasiliły się zamachy terrorystyczne Ukraińskiej Organizacji Wojskowej oraz Organizacji Ukraińskich Nacjonalistów, z drugiej coraz większy wpływ na Ukraińców wywierała szowinistyczna ideologia Dmytra Doncowa. Wszystko to powodowało niepokój wśród ukraińskich biskupów. Pojawiły się ostre reakcje na zamachy, szczególnie ze strony biskupa Grzegorza Chomyszyna, który potępił pogański nacjonalizm i wszystkie jego przejawy. Trochę mniej ostro wypowiadał się w tej sprawie metropolita Andrzej Szeptycki, co wywoływało kontrowersje między oboma pasterzami.
\end{abstract}

Słowa kluczowe: nacjonalizm ukraiński, Andrzej Szeptycki, Grzegorz Chomyszyn 